\begin{tabular}{c}
$\begin{array}{c}\text { Brazilian Journal } \\
\text { of Chemical } \\
\text { Engineering }\end{array}$ \\
\hline
\end{tabular}

ISSN 0104-6632

Printed in Brazil

www.abeq.org.br/bjche

Vol. 27, No. 01, pp. 31 - 39, January - March, 2010

\title{
NUCLEASE p1 IMMOBILIZED ON DEAE CELLULOSE
}

\author{
Lu-E Shi ${ }^{1}, \mathrm{Yu} \mathrm{Yi}^{2}$, Zhen-Xing Tang ${ }^{2}$, Wen-Yue Xiong ${ }^{2}$, Jiang-Feng Mei ${ }^{2}$ and Guo-Qing Ying ${ }^{2 *}$ \\ ${ }^{1}$ College of Life and Environmental Sciences, Hangzhou Normal University, \\ Hangzhou, 310036, Zhejiang, China. \\ ${ }^{2}$ College of Pharmaceutical Science, Zhejiang University of Technology, \\ Hangzhou, 310032, Zhejiang, China. \\ E-mail: gqying@zjut.edu.cn, E-mail: shilue@126.com
}

(Submitted: February 26, 2009 ; Revised: May 5, 2009 ; Accepted: July 6, 2009)

\begin{abstract}
Effects of various factors, such as $\mathrm{pH}$, ionic strength, glutaraldehyde concentration, enzyme amount and immobilization time, on enzyme activity were investigated. The immobilization conditions were optimized by orthogonal experiments. Characterizations of immobilized nuclease p1 were also evaluated. Through orthogonal optimization, the optimal immobilization conditions were as follows: $\mathrm{pH}$ 5.6, ionic strength 0.125 , glutaraldehyde concentration $0.20 \%$ and immobilization time $2.0 \mathrm{~h}$. Optimal pH of immobilized enzyme was 5.8. Optimal temperature of immobilized enzyme was $70^{\circ} \mathrm{C}$. Thermal, operational and storage stabilities of the enzyme were improved after it was immobilized on DEAE cellulose. Michaelis constant $\mathrm{K}_{\mathrm{m}}$ of immobilized enzyme at $69^{\circ} \mathrm{C}$ was found to be $27.21 \mathrm{~g} / 1$ by the Lineweaver-Burk plot.

Keywords: DEAE cellulose; Nuclease p1; Immobilization; Characterization.
\end{abstract}

\section{INTRODUCTION}

Nuclease p1 (EC 3.1.30.1), an extra-cellular enzyme, was first identified by Kuninaka et al. from Penicillium citrinum (Kuninaka et al, 1961). It can cleave 5'-nucleotides (e.g., 5'-AMP, -GMP, -CMP and -UMP) successively from the 3 '-hydroxy termini of 3'-hydroxy-terminated oligonucleotides derived from RNA (Steensma et al., 2004; Kuninaka, 1996). When nuclease $\mathrm{p} 1$ is added during the production of bakers' yeast, the enzyme hydrolyses the yeast RNA efficiently into 5'-GMP. An interesting feature of 5'GMP is that it acts synergistically with monosodium glutamate and thus can largely replace monosodium glutamate in various food products. 5'-Nucleotides have been widely used in food processing and the pharmaceutical industry (Gerald and Tilak, 1991). They can be used to synthesize antivirus and anticancer drugs like an acridine (Ying et al., 2004). Nucleotide derivatives have been applied in the treatment of illnesses of the human central nervous system and circulatory system.

Immobilization of enzymes on insoluble supports is a significant process due to its promising potential for improving enzyme thermal or $\mathrm{pH}$ stability, simplifying product purification, and facilitating enzyme recycling (Blanco et al., 2004; Caramori et al.,2004; Fernandes et al.,2004; Cheng et al., 2006; Goradia et al., 2005; Lai and Lin, 2005; Panya et al., 2005). Therefore, immobilized enzymes have been widely applied in the fields of biocatalysis and biosensors (Dai et al., 2005; Luo et al., 2004; Xu et al., 2006; Xu et al, 2004; Zhao et al., 2007),

To the best of our knowledge, studies of nuclease p1 immobilized on DEAE cellulose rarely have been reported. In this paper, nuclease $\mathrm{p} 1$ was immobilized on DEAE cellulose. Preparation of immobilized enzyme and its characterizations were studied systematically. All the results obtained in this paper would provide a sound basis for further exploration.

*To whom correspondence should be addressed 


\section{MATERIALS AND METHODS}

\section{Materials}

DEAE cellulose was purchased from Wilenman (USA). Groundnut meal was a gift from Hangzhou Zhongmeihuadong Pharmaceutical Co., Ltd. (Hangzhou, China). Glucose kit was purchased from Ningbo Cicheng Reagent Factory (Ningbo, China). Nuclease p1 -producing strain of Penicillium citrinum, used throughout the study, was kindly provided by Hangzhou Meiya Biotechnical Co. Ltd. (Hangzhou, China). All other reagents were of analytical grade.

\section{Production of Nuclease p1}

For nuclease $\mathrm{p} 1$ production, Penicillium citrinum was grown at $30^{\circ} \mathrm{C}$ in a medium $(\mathrm{pH} 7.0)$ consisting of $(\mathrm{w} / \mathrm{v})$ : sucrose $3.0 \%$, potassium dihydrogen phosphate $0.10 \%$, ferrous sulfate $0.010 \%$, sodium nitrate $0.30 \%$, magnesium sulfate $0.050 \%$, potassium chloride $0.050 \%$, and potato extract $20 \%$. This $24 \mathrm{~h}$ grown mother culture $(10 \mathrm{ml})$ was used to inoculate $50 \mathrm{ml}$ of production medium containing $(\mathrm{w} / \mathrm{v})$ : glucose $6.0 \%$, peptone $0.20 \%$, groundnut meal $0.50 \%$, zinc sulfate $0.030 \%$, calcium carbonate $0.040 \%$, and potassium dihydrogen phosphate $0.10 \%$. The $\mathrm{pH}$ of the medium was adjusted to 5.4 with $\mathrm{HCl}$. Erlenmeyer flasks $(500 \mathrm{ml})$ containing 50 $\mathrm{ml}$ of medium were incubated at $28^{\circ} \mathrm{C}$ in an orbital shaker at $240 \mathrm{rpm}$ for $49 \mathrm{~h}$. The nuclease $\mathrm{p} 1$ solution was harvested by centrifugation at $3028 \mathrm{~g}$ at $4^{\circ} \mathrm{C}$ for $10 \mathrm{~min}$, and the supernatant thus obtained was used as the crude enzyme preparation. Crude enzyme activity was $360 \mathrm{U} / \mathrm{ml}$.

\section{Immobilized Method}

1.0 g DEAE cellulose was added to acetate buffer (100 ml, pH 5.4, $0.125 \mathrm{~mol} / \mathrm{l})$. Then it was mixed with glutaraldehyde solution $(4.0 \mathrm{ml}, 25 \%)$ for $2.0 \mathrm{~h}$ at room temperature. This support was washed using acetate buffer. After that, cross-linked DEAE cellulose could be obtained.

Cross-linked DEAE cellulose was mixed with nuclease $\mathrm{p} 1$ solution for $2.0 \mathrm{~h}$ at room temperature. After that, immobilized enzyme support was washed using acetate buffer.

The effect of several factors, such as solution $\mathrm{pH}$, ionic strength, glutaraldehye concentration, immobilization time and enzyme amount, on immobilized enzyme activity were investigated systematically.

\section{Characterizations of Immobilized Enzyme}

\section{Determination of pH Optimum and pH Stability}

Effect of $\mathrm{pH}$ on free enzyme and immobilized enzyme was studied by assaying the enzymes at different $\mathrm{pH}$ values $(4.0-7.5) . \mathrm{pH}$ stability was studied by pre-incubating the enzyme in buffers of different $\mathrm{pH}$ values $(4.0-7.5)$, at $65^{\circ} \mathrm{C}$ for $30 \mathrm{~min}$. The remaining activities were determined by the method described in the item "Nuclease p1 assay".

\section{Determination of Temperature Optimum and Thermal Stability}

To determine the optimum temperature for free enzyme and immobilized enzyme, the enzyme activities of nuclease $p 1$ were measured at various temperatures using RNA as the substrate. The thermal stability was studied by incubating the enzyme at $30,40,50,60,65,70,75,80$ and $90^{\circ} \mathrm{C}$ for $30 \mathrm{~min}$. The residual activities were determined by the method described in the item "Nuclease p1 assay".

\section{Determination of $\mathbf{K}_{\mathrm{m}}$ and $\mathbf{V}_{\max }$}

$\mathrm{K}_{\mathrm{m}}$ and $\mathrm{V}_{\max }$ values of free enzyme and immobilized enzyme were determined by measuring enzyme activities with various concentrations $(0.75$, $1.5,2.25,3.00,3.75,4.50,5.25,6.00,7.50,9.00$, $10.5 \mathrm{mg} / \mathrm{ml}$ ) of RNA substrate. Kinetic constants were calculated as described by the LineweaverBurk method.

\section{Nuclease p1 Assay}

The activity of nuclease p1 was measured by the method of Fujishima et al. (Fujishima et al., 1972) and (Fujimoto et al., 1974). The nuclease p1 activity was measured in terms of the amount of acid-soluble nucleotides produced by RNA hydrolysis, which is catalyzed by nuclease p1. Enzyme solution $(0.10 \mathrm{ml})$ or immobilized enzyme $(0.10 \mathrm{mg})$ was incubated with substrate solution (1.0\% RNA (w/v), $0.125 \mathrm{M}$ acetate buffer, $\mathrm{pH} 5.4,3.0 \mathrm{mM} \mathrm{Zn}^{2+}$ ) at $69^{\circ} \mathrm{C}$ for 15 $\mathrm{min}$. The reaction was stopped by adding $2.0 \mathrm{ml}$ of ice-cold nucleic acid precipitator $(0.25 \%$ ammonium molybdate dissolved in $2.5 \%$ perchloric acid, w/v). The mixture was mantained in an ice-bath for more than $10 \mathrm{~min}$. The precipitated RNA was removed by centrifugation at $3028 \mathrm{~g}$ at $4^{\circ} \mathrm{C}$ for $10 \mathrm{~min}$. The supernatant liquid was diluted 50 -fold with distilled water. The absorbance at $260 \mathrm{~nm}$ of the diluted 
solution was read with a blank incubation without enzymes. The activity (U) of nuclease p1 was calculated according to the following formula:

enzyme activity $(\mathrm{U} / \mathrm{ml})=\mathrm{OD} 260 \times \mathrm{a} \times 4.0 \times 50 /(0.1 \times 15)=$ OD260×a $\times 133.3$;

where $\mathrm{a}$ is a dilution factor of the enzyme before the enzyme activity assay.

One unit of enzyme activity was defined as the amount of enzyme that produced an increase in the optical density of 1.0 in $1 \mathrm{~min}$ at $260 \mathrm{~nm}$.

\section{Protein Assay}

Protein was measured by the method of Bradford (Bradford, 1976). The rapid and sensitive method for quantification of microgram quantities of protein used the principle of protein dye-binding, with bovine serum albumin (BSA) as standard. The concentration of protein during purification studies was calculated from the standard curve.

\section{RESULTS AND DISCUSSION}

\section{Preparation of Immobilized Enzyme}

\section{Effect of pH on Immobilized Enzyme Activity}

Effect of $\mathrm{pH}$ on immobilized enzyme activity was studied. The results are shown in Fig. 1. Immobilized enzyme activity was the highest when $\mathrm{pH}$ of acetate buffer was 5.8 (Fig. 1). Immobilized enzyme activity was very low when the $\mathrm{pH}$ was below 5.0. This was mainly due to different $\mathrm{pH}$, resulting in the difference of charge distribution of the carrier and enzyme, thereby affecting spatial structure of the immobilized enzyme.

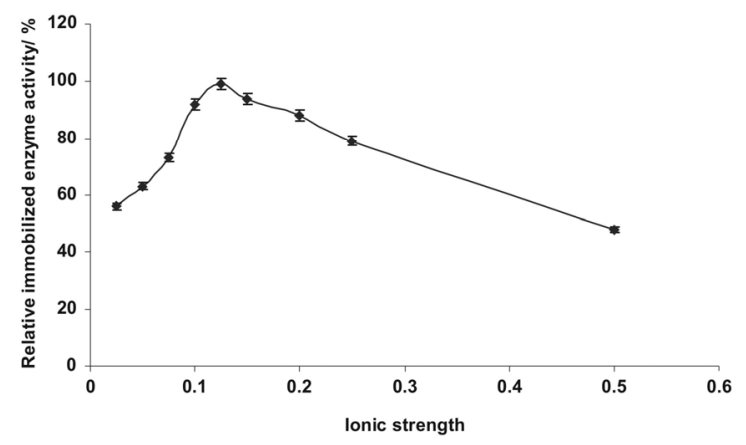

Figure 1: Effect of $\mathrm{pH}$ on immobilized enzyme activity
Effect of Ionic Strength on Immobilized Enzyme Activity

Effect of ionic strength on immobilized enzyme activity was investigated. The results are shown in Fig. 2.

When ionic strength was below 0.125 , immobilized enzyme activity increased with the increase of ionic strength (Fig. 2). But, when ionic strength was higher than 0.125 , immobilized enzyme activity began to decrease with the increase of ionic strength. When ionic strength reached 0.50 , immobilized enzyme activity was only half of the maximum. Competitive adsorption may be existent when ionic strength is high. Thus, immobilized enzyme activity was decreased. Another reason may be enzyme coagulation at high ionic strength. Thus, the buffer solution (ionic strength 0.125 ) was used for enzyme immobilization.

\section{Effect of Glutaraldehyde Concentration on Immobilized Enzyme Activity}

Effect of glutaraldehyde concentration on immobilized enzyme activity was studied. The results are shown in Fig. 3.

Immobilized enzyme activity (DEAE preparation activity) changed greatly with the increase of glutaraldehyde concentration (Fig. 3). When glutaraldehyde concentration was $0.20 \%$, immobilized enzyme activity reached the maximum. However, when glutaraldehyde concentration was more than $0.60 \%$, enzyme activity decreased with the increase of glutaraldehyde concentration. Glutaraldehyde is a crosslinking agent and also a denaturant. When excessive $\mathrm{NH}_{2}$ groups in the enzyme molecule reacted with glutaraldehyde, overcrowding of the enzyme molecule resulted in a change of the enzyme structure.

\section{Effect of Immobilization Time on Immobilized Enzyme Activity}

Effect of immobilization time on immobilized enzyme activity was investigated. The results are shown in Fig. 4.

Immobilized enzyme activity was increased with the increase of immobilization time. When the immobilization time reached $2.0 \mathrm{~h}$, the maximum enzyme activity was obtained. Immobilized enzyme activity remained unchanged even if the immobilization time was increased. This indicates that the available space on the immobilization carrier becomes saturated with the increase of the immobilization time. 


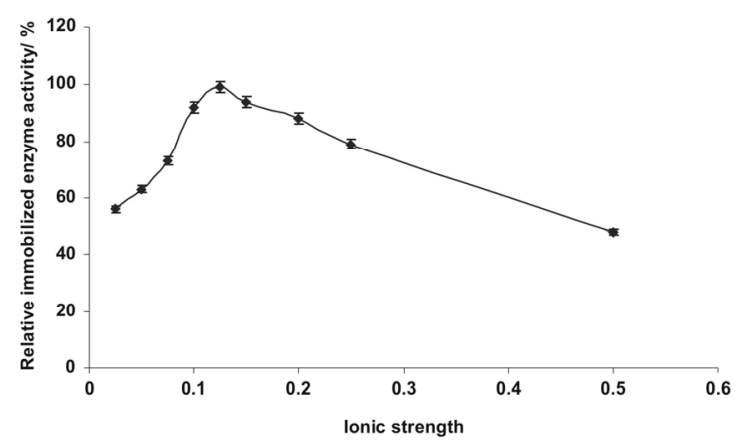

Figure 2: Effect of ionic strength on immobilized enzyme activity

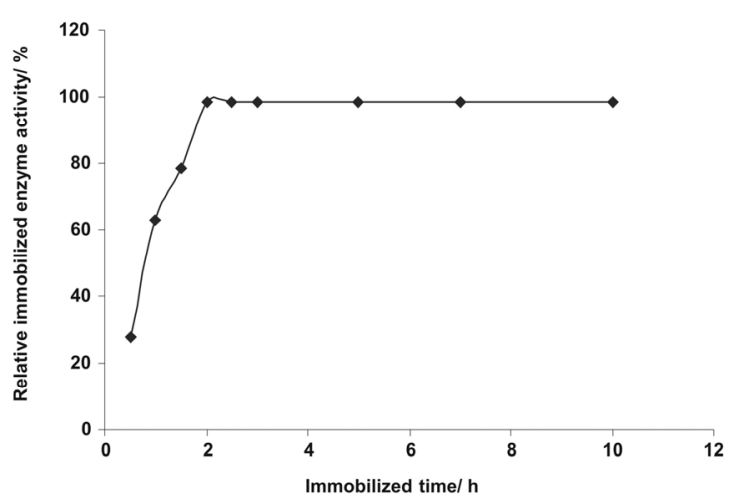

Figure 4: Effect of immobilization time on immobilized enzyme activity.

\section{e) Effect of Enzyme Amount on Immobilized Enzyme Activity}

Effect of enzyme amount on immobilized enzyme activity was investigated. The results are shown in Fig. 5. Immobilized enzyme activity increased with the increase of enzyme amount from $0.5 \mathrm{ml}$ to $6.0 \mathrm{ml}$ and remained unchanged with the increase of enzyme amount (Fig. 5). Before the binding sites on the surface of DEAE cellulose were saturated, immobilized enzyme activity increased with enzyme amount. However, once it was saturated, immobilized enzyme activity can not be increased by an increase of enzyme amount. When the enzyme amount was $6.0 \mathrm{ml}$, enzyme activity recovery was only $50 \%$ (Fig. 5). So, an enzyme amount of $4.0 \mathrm{ml}$ was chosen for enzyme immobilization.

\section{f) Optimum Immobilization Conditions}

According to the results of One-factor-at-a-time method, four factors that mainly affected the

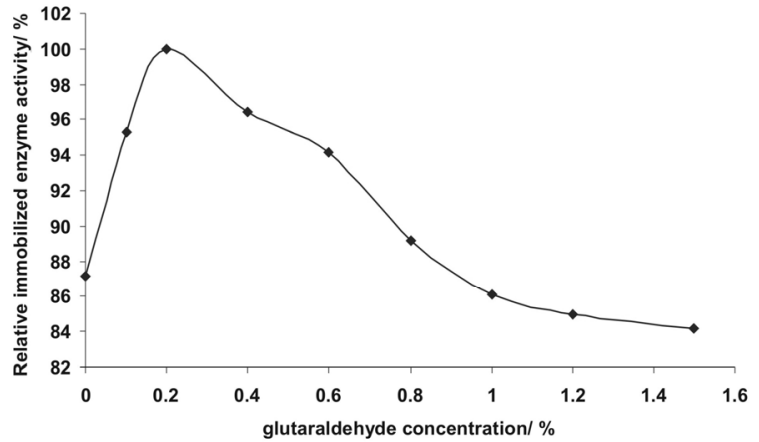

Figure 3: Effect of glutaraldehyde concentration on immobilized enzyme activity.

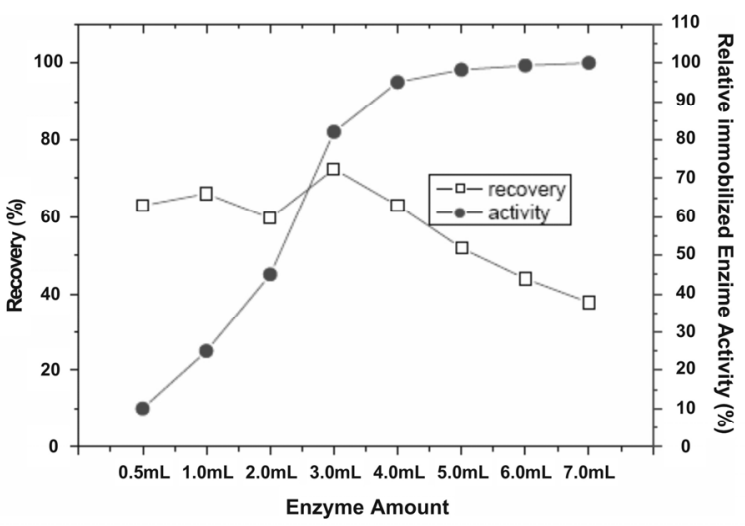

Figure 5: Effect of enzyme amount on immobilized enzyme activity

enzyme activity were selected to determine which factors were the significant factors. These factors were $\mathrm{pH}$, ionic strength, glutaraldehyde concentration and immobilization time. Orthogonal design is shown in Tab. 1. Orthogonal experimental results and analysis of the results are shown in Tab. 2 and 3, respectively.

The factors were ranked according to $\mathrm{R}$ (contribution percentage), namely, $\mathrm{B}>\mathrm{A}>\mathrm{D}>\mathrm{C}$. The optimal condition was $\mathrm{A}_{3} \mathrm{~B}_{3} \mathrm{C}_{2} \mathrm{D}_{1}$ (Tab. 1 and 2). That was $\mathrm{pH} 5.6$, ionic strength 0.125 glutaraldehyde concentration $0.20 \%$ and immobilization time $2.0 \mathrm{~h}$.

Significant factors affecting enzyme activity were $\mathrm{pH}$ and ionic strength (Tab. 3). Therefore, during preparation of immobilized enzyme, the most important thing was to control $\mathrm{pH}$ and ionic strength.

To confirm the optimal conditions, a set of four replicate experiments with the optimal conditions were carried out. The average relative enzyme activity was $100.3 \%$. 
Table 1: Levels of different factors

\begin{tabular}{|l|c|r|r|}
\hline \multicolumn{1}{|c|}{ Factors } & Level 1 & Level 2 & Level 3 \\
\hline A pH & 5.0 & 5.3 & 5.6 \\
B ionic strength & 0.075 & 0.10 & 0.125 \\
C glutaraldehyde concentration (\%) & 0.1 & 0.20 & 0.40 \\
D immobilization time (h) & 2.0 & 2.5 & 3.0 \\
\hline
\end{tabular}

Table 2: The result of orthogonal array

\begin{tabular}{|c|c|c|c|c|c|}
\hline Run & A & B & C & D & Relative enzyme activity (\%) \\
\hline 1 & 1 & 1 & 1 & 1 & 81.0 \\
2 & 1 & 2 & 2 & 2 & 100 \\
3 & 1 & 3 & 3 & 3 & 93.4 \\
4 & 2 & 1 & 2 & 3 & 94.0 \\
5 & 2 & 2 & 3 & 1 & 95.5 \\
6 & 2 & 3 & 1 & 2 & 84.3 \\
7 & 3 & 1 & 3 & 2 & 96.6 \\
8 & 3 & 2 & 1 & 3 & 100 \\
9 & 3 & 3 & 2 & 1 & \\
$\mathrm{~K}_{1}$ & 88.17 & 83.13 & 91.07 & 91.87 & \\
$\mathrm{~K}_{2}$ & 91.33 & 93.70 & 91.33 & 89.93 & \\
$\mathrm{~K}_{3}$ & 93.63 & 96.30 & 90.74 & 91.33 & \\
$\mathrm{R}$ & 5.46 & 13.17 & 0.57 & 1.94 & \\
\hline
\end{tabular}

Table 3: Results of ANOVA and optimal factor levels

\begin{tabular}{|l|r|r|r|r|}
\hline \multicolumn{1}{|c|}{ Factors } & MS & DF & F & Significance \\
\hline $\mathrm{pH}$ & 45.20 & 2 & 83.40 & $*$ \\
ionic strength & 291.78 & 2 & 538.33 & $*$ \\
glutaraldehyde concentration & 0.54 & 2 & 1.00 & \\
immobilized time & 5.98 & 2 & 11.04 & \\
Error & 0.54 & 2 & & \\
\hline
\end{tabular}

DF degree of freedom, MS mean square, R contribution percentage

$*$ Significance $<0.05$

\section{CHARACTERIZATIONS OF IMMOBILIZED ENZYME}

\section{Optimum pH}

Compared with free enzyme, the optimum $\mathrm{pH}$ of immobilized enzyme increased 0.5 units (Fig. 6). This result is in agreement with that of peroxidase immobilized on DEAE cellulose. The $\mathrm{pH}$-optimum of immobilized peroxidase shifted to 5.6, while free enzyme showed a pH-optimum at $\mathrm{pH} \quad 5.0$ (Kulshrestha and Husain, 2006). These differences in the behaviors of free and immobilized enzyme could be explained by the poly-cationic nature of a support like DEAE- cellulose that attracts more $\mathrm{OH}^{-}$ions around the immobilized enzyme, thus making the $\mathrm{pH}$ of the enzyme's micro-environment higher than the bulk solution. Immobilized enzyme therefore requires a higher $\mathrm{pH}$ for optimal activity than free enzyme.

\section{pH Stability of Enzyme}

The $\mathrm{pH}$ stability of the enzyme was enhanced when the enzyme was immobilized (Fig. 7). It was not sensitive to $\mathrm{pH}$ change. This result is the same as in other work where we found that the $\mathrm{pH}$ stability of nuclease $\mathrm{p} 1$ was increased when it was immobilized on chitosan microspheres (not published). Enzyme may be encapsulated in the micro-environment of DEAEcellulose. The change of solution $\mathrm{pH}$ did not affect the protection layer of the supports or maybe there is an interaction between the support and nuclease p1, making the enzyme conformation more stable.

\section{Optimum Temperature}

The effect of temperature on enzyme activity is shown in Fig. 8. Optimum temperature of immobilized enzyme was increased $10^{\circ} \mathrm{C}$. This result is similar to that reported by Fahmy et al. (Fashmy et 
al., 1998). In their study, urease was immobilized on DEAE-cellulose. The optimum temperature of immobilized enzyme was shifted to $65^{\circ} \mathrm{C}$, whereas free enzyme had an optimum temperature of approximately $55^{\circ} \mathrm{C}$. Similarly, optimum temperature of immobilized single-strand specific nuclease on gelatine-alginate was increased to $65^{\circ} \mathrm{C}$ (Reddyand Shankar, 1987). This means that immobilized enzyme has a higher resistance to the change of temperature than free enzyme. At low temperatures, the activity of free enzyme was higher than that of immobilized enzyme. This may reflect molecular diffusion resistance and the conformational change of enzyme immobilized on the supports. At high temperatures, the enzyme activity of both free enzyme and immobilized enzyme decreased sharply with the increase of temperature. A possible explanation is that, with the increase of temperature, the concentration of the enzyme molecules opened up and they ultimately lost their biocatalytic activity.

\section{Temperature Stability of Enzyme}

Free and immobilized enzyme was incubated at different temperatures for half an hour, respectively

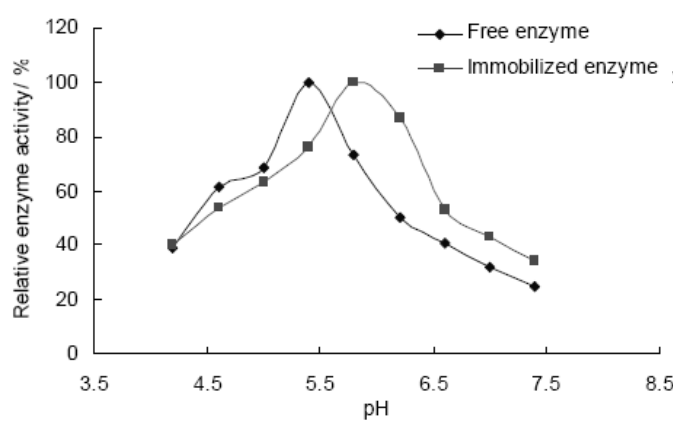

Figure 6: optimum $\mathrm{pH}$ of free enzyme and immobilized enzyme
(Fig. 9). The activity of both free enzyme and immobilized enzyme decreased sharply with increasing temperature up to $70^{\circ} \mathrm{C}$. The activity of immobilized enzyme on DEAE cellulose remained more than $85 \%$ after it was incubated at $70^{\circ} \mathrm{C}$ for 9.0 h (Fig. 10). However, only 63\% of the activity of free enzyme remained under the same conditions. Compared with free enzyme, the thermal stability of enzyme immobilized on DEAE cellulose was greatly increased, probably because of the greater stability of the three-dimensional structures of immobilized enzyme. The improvement of the optimum temperature and thermal stability of the enzyme is favorable for its industrial application. Kulshresha and Hussin studied the thermal denaturation behavior of free and immobilized peroxidase on DEAE cellulose (Karboune et al., 2005). In their study, free peroxidase incubated at $60^{\circ} \mathrm{C}$ for $2 \mathrm{~h}$ retained $43 \%$ of its initial enzyme activity, while the immobilized enzyme incubated under similar conditions was significantly more stable to heat inactivation. The immobilized peroxidase exhibited $60 \%$ of the original activity after $2 \mathrm{~h}$ of heat treatment. Similar results were also reported by Fahmy et al. (Fashmy et al., 1998).

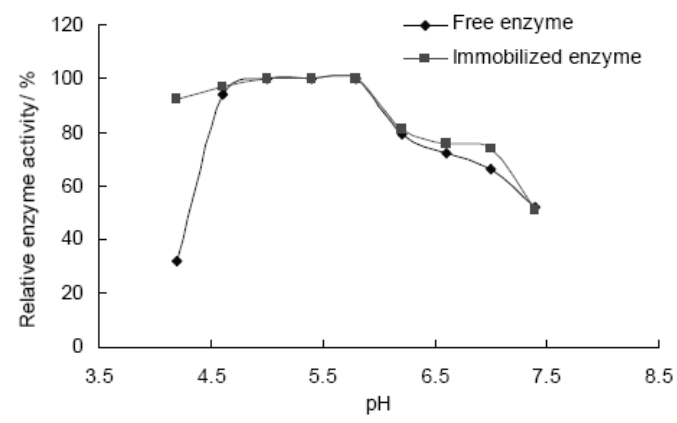

Figure 7: pH stability of free and immobilized enzyme

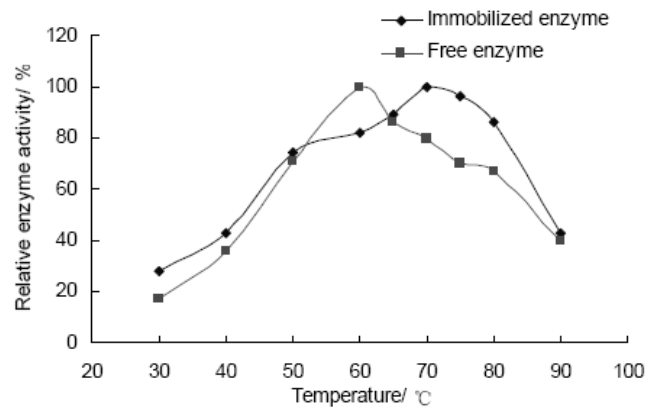

Figure 8: Optimum temperature of free and immobilized enzyme 


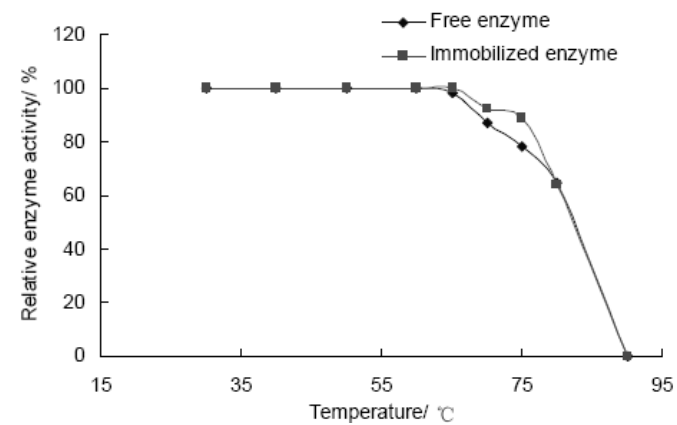

Figure 9: Temperature stability of free and immobilized enzyme

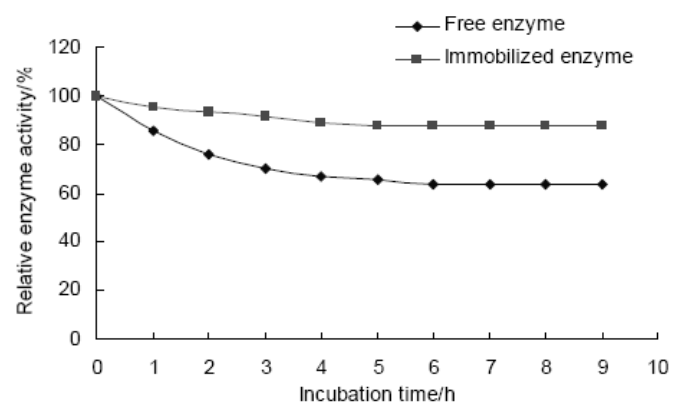

Figure 10: Temperature stability of free enzyme and immobilized enzyme after a long time storage

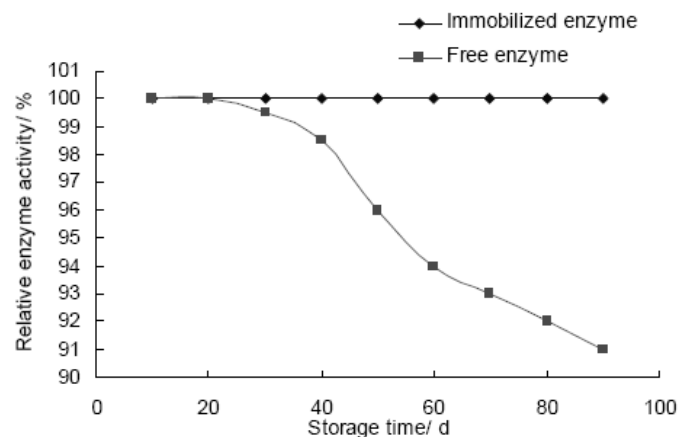

Figure 11: storage stability of free enzyme and immobilized enzyme

\section{Storage Stability of Enzyme}

Storage stability of immobilized enzyme was quite good (Fig. 11). The activity remained unchanged at $4^{\circ} \mathrm{C}$ after 90 days. However, more than $10 \%$ activity of free enzyme was lost after 90 days. Generally, the combination of immobilized carrier with enzyme increases enzyme stability. The increase of storage stability of immobilized enzyme is very favourable for its industrial application. Fahmy et al. studied storage stability of free and immobilized enzyme on DEAE cellulose at $4^{\circ} \mathrm{C}$ and $25^{\circ} \mathrm{C}$, respectively. Their results shown storage stability of immobilized enzyme was better than that of free enzyme (Fashmy et al., 1998). This result is consistent with our result.

\section{Measurement of the Michaelis Constant}

Determination of free and immobilized nuclease p1 $\mathrm{K}_{\mathrm{m}}$ and $\mathrm{V}_{\max }$, was studied. The results are shown in Fig. 12 and Tab. 4. The Michaelis constant of the immobilized enzyme was a little higher than that of the free enzyme (Tab. 4 and Fig. 12). This increase may have resulted from conformational and steric modifications introduced by the attachment of the enzyme to the support and to mass transfer resistances inherent in the morphology of the support used, thus reducing the affinity of the substrate for the active site of the enzyme. This increase in $\mathrm{K}_{\mathrm{m}}$ of the immobilized enzyme is in agreement with the result reported by Fahmy et al. $\mathrm{K}_{\mathrm{m}}$ was about 3.8 times higher for immobilized enzyme than for free enzyme (Fashmy et al., 1998).

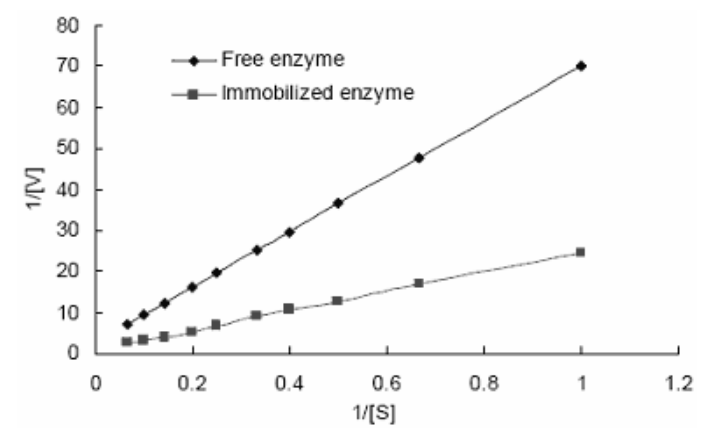

Figure 12: Lineweaver-Burk plots for the free enzyme and immobilized enzyme.

The enzyme activity was determined under standard assay conditions. Symbols: S RNA concentration $(\mathrm{mg} / \mathrm{ml}) ; \mathrm{V}$ reaction velocity (mg/mlmin) 
Table 4: Michaleis constants of free and immobilized enzyme

\begin{tabular}{|l|c|c|}
\hline \multicolumn{1}{|c|}{ Category } & $\mathbf{K}_{\mathbf{m}} \mathbf{( m g / m I )}$ & $\mathbf{V}_{\max }(\mathbf{m g} / \mathbf{m l} \mathbf{m} \mathbf{m i n})$ \\
\hline Free enzyme & 24.28 & 0.54 \\
Immobilized enzyme & 27.21 & 1.14 \\
\hline
\end{tabular}

\section{CONCLUSIONS}

Nuclease p1 immobilized on DEAE cellulose was studied in this paper. Optimal immobilization conditions were as follows: $\mathrm{pH}$ 5.6, ionic strength 0.125 , glutaraldehyde concentration $0.20 \%$ and immobilization time $2.0 \mathrm{~h}$. Characterizations of the immobilized enzyme showed that the optimum $\mathrm{pH}$, optimum temperature and storage stability are significantly higher than those of free enzyme. This made immobilized enzyme better adapted to the change of $\mathrm{pH}$ and temperature, more conducive to industrial production.

\section{REFERENCES}

Blanco, R. M., Terreros, P., Fernández-Pérez, M., Otero, C. and Diáz-González, G., Functionalization of mesoporous silica for lipase immobilization: Characterization of the support and the catalysts. Journal of Molecular Catalysis B: Enzymatic, v. 30, 83-93 (2004).

Bradford, M., A rapid and sensitive method for quantitation of microgram quantities of protein using the principle of protein dye-binding. Analytical Biochemistry, v. 72, 248-254 (1976).

Caramori, S. S. and Fernandes, K. F., Covalent immobilisation of horseradish peroxidase onto poly(ethylene terephthalate)-poly(aniline) composite. Process Biochemistry, v. 39, 883-888 (2004).

Cheng, J., Yu, S. M. and Zuo, P., Horseradish peroxidase immobilized on aluminum-pillared interlayered clay for the catalytic oxidation of phenolic wastewater. Water Research, v. 40, 283290 (2006).

Dai, Z., Ju, H. and Chen, H., Mesoporous Materials Promoting Direct Electrochemistry and Electrocatalysis of Horseradish Peroxidase. Electroanalysis, v. 17, 862-868 (2005).

Fashmy, A. S., Bagos, V. B. and Mohammed, T. M., Immobilization of Citrullus vulgaris urease on cyanuric chloride DEAE-cellulose ether, preparation and properties. Bioresource Technology, v. 64, 121129 (1998).

Fernandes, K. F., Lima, C. S., Lopes, F. M. and Collins, C. H., Properties of horseradish peroxidase immobilised onto polyaniline. Process Biochemistry, v. 39, 957-962 (2004).

Fujimoto, M., Kuninaka, A., Yoshino, H., Purification of a nuclease from Penicillium citrinum. Agricultural \& Biological Chemistry, v. 38, 777783 (1974).

Fujishima, T., Uchida, K. and Yushino, H., Enzyme production by molds in sponge culture. Journal of Fermentation Technology, v. 50, 724-730 (1972).

Gerald, R. and Tilak, W., Yeast derived products in Yeast technology. (2nd ed.), New York (1991).

Goradia, D., Cooney, J., Hodnett, B. K. and Magner, E., The adsorption characteristics, activity and stability of trypsin onto mesoporous silicates. Journal of Molecular Catalysis B, Enzymatic, v. 32, 231-239 (2005).

Karboune, S., Archelas, A., Furstoss, R., Baratti, J., Immobilization of epoxide hydrolase from Aspergillus niger onto DEAE-cellulose: enzymatic properties and application for the enantioselective resolution of a racemic epoxide. Journal of Molecular Catalysis B, Enzymatic, v. 32, 175-183 (2005)

Kulshrestha, Y. and Husain, Q., Direct immobilization of peroxidase on DEAE cellulose from ammonium sulfate fractionated proteins of bitter gourd (Momordica charantia). Enzyme and Microbial Technology, v. 38, 470-477 (2006).

Kuninaka, A., Nucleotides and related compounds. Germany (1996).

Kuninaka, A., Kibi, M., Yoshino, H. and Sagaguchi, K., Studies on 50-phosphodiesterase in microorganisms. Part II, Properties and application of Penicillium citrinum 50-phosphodiesterase. Agricultural \& Biological Chemistry, v. 25, 693-701 (1961).

Lai, Y. C. and Lin, S. C., Application of immobilized horseradish peroxidase for the removal of $p$ chlorophenol from aqueous solution. Process Biochemistry, v. 40, 1167-1174 (2005).

Luo, X. L., Xu, J. J., Zhao, W. and Chen, H. Y., Glucose biosensor based on ENFET doped with $\mathrm{SiO} 2$ nanoparticles. Sensors and Actuators B, Chemical, v. 97, 249-255 (2004).

Panya, P. H., Jasra, R. V., Newalkar, B. L. and Bhatt, P. N., Studies on the activity and stability of immobilized $\alpha$-amylase in ordered mesoporous silicas. Microporous and Mesoporous Materials, v. 77, 67-77 (2005).

Reddy, L. G. and Shankar, V., Immobilization of single-strand specific nuclease (S1 nuclease) from Aspergillus oryzae. Applied Biochemistry and Biotechnology, v. 14, 231-240 (1987).

Steensma, A., van Dijck, P. W. M, and Hempenius, R. A., Safety evaluation of phosphodiesterase 
derived from Leptographium procerum. Food and Chemical Toxicology, v. 42, 935-944 (2004).

Xu, J. Z., Zhang, Y., Li, G. X. and Zhu, J. J., An electrochemical biosensor constructed by nanosized silver particles doped sol-gel film. Materials Science and Engineering, C. v. 24, 833836 (2004).

Xu, Q., Mao, C., Liu, N. N., Zhu, J. J. and Shen, J., Immobilization of horseradish peroxidase on $O$ carboxymethylated chitosan/sol-gel matrix. Reactive and Functional Polymers, v. 66, 863-870 (2006).
Ying, G. Q., Shi, L.E., Tang, Z.X. and Shan, J. F., The applications of mononucleotides and produing methods. Food Research and Development, v. 25, 120-123 (2004).

Zhao, Z. X., Qiao, M. Q., Yin, F., Shao, B., Wu, B. Y., Wang, Y. Y., Wang, X. S., Qin, X., Li, S., $\mathrm{Yu}, \mathrm{L}$. and Chen, Q., Amperometric glucose biosensor based on self-assembly hydrophobin with high efficiency of enzyme utilization. Biosensors and Bioelectronics, v. 22, 3021-3027 (2007). 